\title{
Synergistic Sintering of Lignite Fly Ash and Steelmaking Residues towards Sustainable Compacted Ceramics
}

\author{
V. G. Karayannis, ${ }^{1}$ A. K. Moutsatsou, ${ }^{2}$ A. N. Baklavaridis, ${ }^{1}$ \\ E. L. Katsika, ${ }^{2}$ and A. E. Domopoulou ${ }^{1}$ \\ ${ }^{1}$ Department of Environmental Engineering, Technological Education Institute of Western Macedonia, Kila, 50100 Kozani, Greece \\ ${ }^{2}$ School of Chemical Engineering, National Technical University of Athens, Zografou Campus, 15773 Athens, Greece \\ Correspondence should be addressed to V. G. Karayannis; vkarayan@teiwm.gr
}

Received 10 April 2017; Accepted 1 June 2017; Published 4 July 2017

Academic Editor: Peter Majewski

Copyright (C) 2017 V. G. Karayannis et al. This is an open access article distributed under the Creative Commons Attribution License, which permits unrestricted use, distribution, and reproduction in any medium, provided the original work is properly cited.

\begin{abstract}
The development of value-added ceramic materials deriving only from industrial by-products is particularly interesting from technological, economic, and environmental point of views. In this work, the synergistic sintering of ternary and binary mixtures of fly ash, steelmaking electric arc furnace dust, and ladle furnace slag for the synthesis of compacted ceramics is reported. The sintered specimens' microstructure and mineralogical composition were characterized by SEM-EDS and XRD, respectively. Moreover, the shrinkage, apparent density, water absorption, and Vickers microhardness (HV) were investigated at different sintering temperatures and raw material compositions. The characterization of the sintered compacts revealed the successful consolidation of the ceramic microstructures. According to the experimental findings, the ceramics obtained from fly ash/steel dust mixtures exhibited enhanced properties compared to the other mixtures tested. Moreover, the processing temperature affected the final properties of the produced ceramics. Specifically, a 407\% HV increase for EAFD and a 2221\% increase for the FA-EAFD mixture were recorded, by increasing the sintering temperature from 1050 to $1150^{\circ} \mathrm{C}$. Likewise, a $972 \%$ shrinkage increase for EAFD and a $577 \%$ shrinkage increase for the FA-EAFD mixture were recorded, by increasing the sintering temperature from 1050 to $1150^{\circ} \mathrm{C}$. The research results aim at shedding more light on the development of sustainable sintered ceramics from secondary industrial resources towards circular economy.
\end{abstract}

\section{Introduction}

Management and valorization of huge amounts of waste byproducts (solid residues), recovered from industrial activities, still remain a major problem in many countries. In steel industry, the production of 1 ton of steel results in the generation of 2-4 tons of various types of wastes [1]. Therefore, the valorization of solid by-products recovered from steelmaking and metal industries would induce significant economic and environmental benefits [2]. However, the suitable disposal and handling of wastes of this category remain both dangerous and expensive $[3,4]$. Three types of solid residues mainly derive from the steel industries, namely, blast furnace slag, steel slag, and electric arc furnace dust. Blast furnace slag and steel slag are being used as competitive raw materials in the mineral and cement industry [1]. Specifically, steel slag is widely used in road and pavement construction materials, while blast furnace slag usage in the cement industry is currently increasing due to the reduction of production cost that is achieved in the final cementitious products. The recycling of electric arc furnace dust (EAFD) is also very important due to the fact that it is one of the major steel industry by-products produced in large quantities worldwide and considered as potentially hazardous $[3,5]$. In that sense, various efforts aiming at the effective recycling of EAFD have been proposed. It has been reported that the addition of up to 15\% EAFD in the ceramic clay body leads to the production of ceramic specimens with good physical and mechanical properties while the leachability of EAFD lies within acceptable limits [6]. Moreover, clay mixtures with up to 5\% EAFD could be effectively used for the production of bricks and roof tiles [7]. 
TABLE 1: The solid residue compositions of the specimens.

\begin{tabular}{lcccc}
\hline S/N & Sample name & EAFD (mass $\%)$ & FA (mass\%) & LFS (mass\%) \\
\hline 1 & FA & 0 & 100 & 0 \\
2 & EAFD & 100 & 0 & 0 \\
3 & FA-EAFD & 50 & 50 & 0 \\
4 & FA-EAFD-LFS & 33.33 & 33.33 & 33.33 \\
\hline
\end{tabular}

On the other hand, coal fly ash (FA) is a fine powder obtained by the electrostatic precipitation of dust-like particles from the flue gases of lignite-fed boilers. In Greece, more than 8 million tons of ash are produced annually from lignite combustion power stations. Specifically, $80 \%$ of the total amount of ash derives from the Northern Greece (Region of Western Macedonia), where the main lignite deposits are located. Nowadays, limited amounts of FA are being reused, while more than $80 \%$ of the overall FA output is directly deposited into ponds and landfills. However, the contamination from FA deposits can easily occur, because the FA particles usually contain potentially hazardous trace elements (heavy metals) due to their high surface area $[8,9]$. Subsequently, there are serious concerns that this situation will possibly cause severe and irreversible long-term environmental effects. In order to avert this environmental impact, the FA valorization in construction and other civil engineering applications should be considered. Several studies were already focused upon the addition of various loadings of FA in clayey mixtures, for the production of conventional extruded or sintered ceramics or even composite materials, destined for construction applications [10-15]. At the same time, several studies reported the usage of FA for the production of advanced ceramics and composite materials [16, 17].

As aforementioned, fly ash (FA) and electric arc furnace dust (EAFD) are two of the most abundant industrial byproducts. Since FA and EAFD consist of several oxides, compositionally appropriate mixtures could be used as raw (starting) materials in the ceramic and construction industries. On the other hand, it has been reported that various mixtures including several solid industrial wastes (containing $\mathrm{SiO}_{2}, \mathrm{Al}_{2} \mathrm{O}_{3}$, and $\mathrm{CaO}$ ) could be used for the production of ceramics, glass-ceramics, and cement-based materials destined for construction applications [18-21]. Moreover, residues generated from galvanization and metal finishing processes and containing toxic heavy metals can be thermally treated in the presence of fly ash and/or clay for the immobilization of hazardous agents into novel ceramics to be used in building, construction, and other applications [3, 2024]. However, limited works are adverted to the development of sintered ceramics by synergistically using FA and steel industry powdery residues $100 \%$ as the raw materials. Karamberi and Moutsatsou reported the production of glass and glass-ceramics from steel and $\mathrm{Fe}-\mathrm{Ni}$ production slags by vitrification [18].

In the current research, the development of sintered ceramic compacts consisting of fly ash (FA), electric arc furnace dust (EAFD), and ladle furnace slag (LFS) is reported. The physicomechanical properties of the ceramics produced are studied at different sintering temperatures and raw material mixture compositions.

\section{Experimental}

2.1. Raw Materials. EAFD and LFS were obtained from a Greek steel industry, while FA was collected from a lignite-fed power station situated in Northern Greece. All materials were used as-received without any further treatment. The chemical composition of these materials was determined using a Spectro X-Lab 2000 X-ray Fluorescence (XRF) spectrometer. The analysis shows that EAFD contains Fe and $\mathrm{Zn}$ oxides, in quantities higher than $50 \mathrm{wt} \%$. Several other oxides of $\mathrm{Pb}, \mathrm{Ca}$, $\mathrm{Na}, \mathrm{Si}, \mathrm{Mn}$, and $\mathrm{Mg}$ were also detected in EAFD. LFS mainly contains $\mathrm{Fe}, \mathrm{Ca}$, and $\mathrm{Si}$ oxides in quantities higher than $80 \mathrm{wt} \%$. Moreover, $\mathrm{CaO}$ concentrations higher than $50 \mathrm{wt} \%$ were found in LFS, while $\mathrm{SiO}_{2}$ and $\mathrm{Fe}$ and $\mathrm{Al}$ oxides are also present. The FA used was a highly calcareous one. The $\mathrm{CaO}$ and $\mathrm{SiO}_{2}$ content (wt $\%$ ) exceeded $60 \%$, while $\mathrm{Al}_{2} \mathrm{O}_{3}$ and $\mathrm{Fe}_{2} \mathrm{O}_{3}$ were also detected.

2.2. Preparation of Ceramic Compacts. Mixtures of the asreceived industrial residues (in equal compositions) were prepared. The residue compositions of the specimens prepared for this study are shown in Table 1.

The initial mixtures were then compressed into discshaped green compacts (13 $\mathrm{mm}$ in diameter) by uniaxial coldpressing in a stainless steel die (SPECAC, 15011). The compaction pressure has been optimized, prior to the fabrication of the final samples, so as to obtain sample having sufficient green density and strength for subsequent handling and thermal treatment. The green specimens were heated at $10^{\circ} \mathrm{C} / \mathrm{min}$ up to the designated processing (sintering) temperature of $1050^{\circ} \mathrm{C}$ or $1150^{\circ} \mathrm{C}$. The samples were then kept at the peak temperature for $2 \mathrm{~h}$. The thermal treatment was carried out in a laboratory chamber furnace, under controlled conditions. Finally, the sintered samples were gradually cooled down to ambient temperature, inside the furnace (Thermoconcept, $\mathrm{KL06/13)}$. Lower sintering temperature $\left(950^{\circ} \mathrm{C}\right)$ was also tested, but the produced ceramic samples were not successfully consolidated (SEM micrograph is provided in Results and Discussion). Photographs of the initial (nonsintered) and sintered disc-shaped ceramic samples are shown in Figure 1.

2.3. Characterization of Ceramic Compacts. Phase identification of the ceramic samples was carried out via X-ray diffraction (XRD) measurements (Siemens, Diffractometer D-5000). Microstructural examination of the specimens was realized by Scanning Electron Microscopy (SEM-Jeol, 


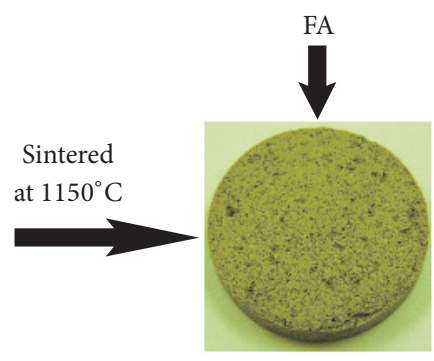

(a)

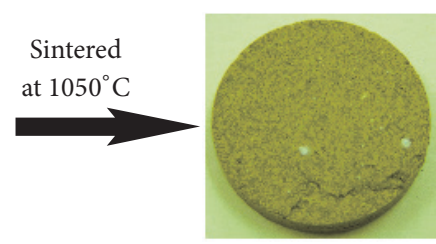

(b)

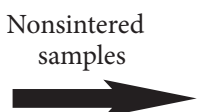

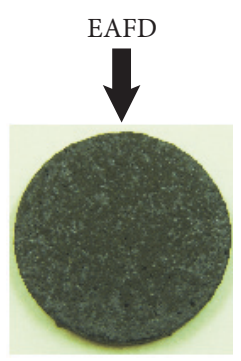

(c)

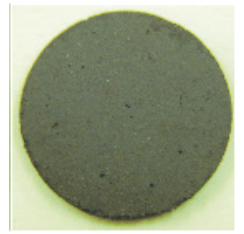

(d)

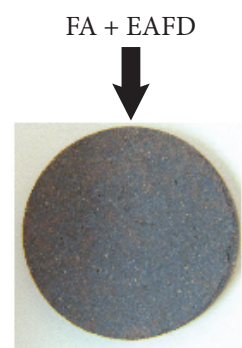

(e)

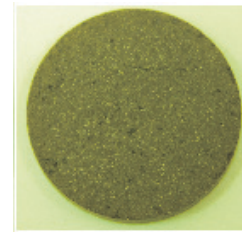

(f)

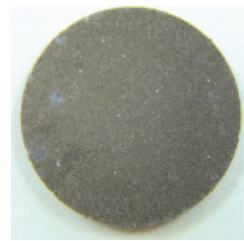

(g)

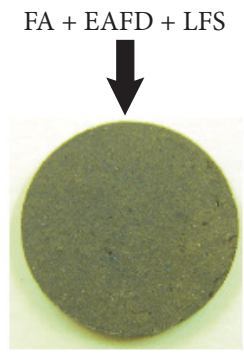

(h)

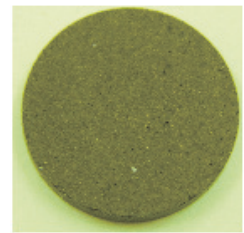

(i)

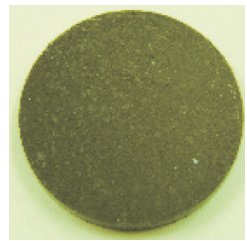

(j)

FIGURE 1: Selected photographs of the disc-shaped ceramic specimens (with diameter $13 \mathrm{~mm}$ ) consisting of $100 \mathrm{wt} . \% \mathrm{FA}(\mathrm{a}, \mathrm{b}), 100 \mathrm{wt} \%$ EAFD (c, d), 50-50 wt.\% FA + EAFD mixture (e, f, g), and 33,3-33,3-33,3 wt.\% FA + EAFD + LFS mixture (h, i, j). Sintered samples at 1150 ${ }^{\circ} \mathrm{C}$ (a, c, e, $\mathrm{h}), 1050^{\circ} \mathrm{C}(\mathrm{b}, \mathrm{d}, \mathrm{f}, \mathrm{i})$, and nonsintered samples $(\mathrm{g}, \mathrm{j})$ are shown from top to bottom, respectively.

JSM-6400) coupled with Energy Dispersive X-ray Spectroscopy (EDX) analysis. The apparent density was determined by means of a specific apparatus (Shimadzu, SMK401AUW220V) according to the Archimedes principle. Microhardness was measured using a Vickers indenter (Shimadzu, HMV-2T) by applying a load of $200 \mathrm{~g}$ (dwell time of $15 \mathrm{~s}$ ) on the specimen surface. The mean hardness values were calculated over five valid indentations per specimen.

\section{Results and Discussion}

XRD measurements were conducted in order to identify the mineralogical phases that are present in the raw materials as well as in the mixtures and the sintered samples as well. In Figure 2, the XRD patterns of the sintered samples (at $1050^{\circ} \mathrm{C}$ ) containing only EAFD, FA, LFS, and the mixture EAFD-FA-LFS are provided. It can be seen from Figure 2 that the sintered samples are composed of several crystalline phases. The main crystalline phases identified are magnetite $\left(\mathrm{Fe}_{3} \mathrm{O}_{4}\right)$, hematite $\left(\mathrm{Fe}_{2} \mathrm{O}_{3}\right)$, zinc oxide $(\mathrm{ZnO})$, gehlenite $\left(\mathrm{Ca}_{2} \mathrm{Al}\left[\mathrm{AlSiO}_{7}\right]\right), \mathrm{MgAl}_{2} \mathrm{Si}_{3} \mathrm{O}_{10}$, quartz $\left(\mathrm{SiO}_{2}\right)$, cyanite $\left(\mathrm{Al}_{2} \mathrm{SiO}_{5}\right)$, lime $(\mathrm{CaO})$, and portlandite $\left(\mathrm{Ca}(\mathrm{OH})_{2}\right) . \mathrm{Fe}_{3} \mathrm{O}_{4}$ and $\mathrm{ZnO}$ should mainly originate from EAFD. Gehlenite derives from carbonate-silicate-spinel reactions. Both the gehlenite and even the $\mathrm{MgAl}_{2} \mathrm{Si}_{3} \mathrm{O}_{10}$ formation should be associated with the presence of FA in the sample $[25,26]$. It should be noted that most of the crystalline phases identified were also present in the starting raw materials (as-received industrial by-products). However, the thermal treatment of the compacted mixture leads to changes in the intensity of the peaks corresponding to the aforementioned mineralogical phases. The sintered mixture (FA-EAFD-LFS) also contains an amorphous phase, which becomes evident from a hump in the pattern recorded between $2 \theta=30^{\circ}$ and $2 \theta=35^{\circ}$ (Figure 2). The occurrence of amorphous phase may be mainly ascribed to bloating of LFS particles and secondarily to the aluminosilicate glass which is present in FA $[27,28]$.

The role of sintering temperature in the mineralogical phase composition of the samples was also studied with XRD. Specifically, the effect of sintering temperature on the phase composition of the ceramic samples was studied for the FAEAFD mixture. In Figure 3, XRD patterns of the sintered (at $\left.1050^{\circ} \mathrm{C}\right) \mathrm{FA}, \mathrm{EAFD}$, and its mixture sintered at two different peak temperatures: 1050 and $1150^{\circ} \mathrm{C}$. No significant mineralogical phase changes are observed in the XRD patterns of Figure 3, with increasing the sintering temperature from 1050 to $1150^{\circ} \mathrm{C}$.

SEM-EDS examination sheds light into the surface morphology and the elemental composition of the ceramic samples. In Figures 4(a) and 4(b), SEM images of the binary EAFD-FA mixture sintered at $1150^{\circ} \mathrm{C}$ are provided, while images of the ternary EAFD-FA-LFS mixture sintered at $1150^{\circ} \mathrm{C}$ are shown in Figures 4(c) and 4(d). The EAFD-FA sample exhibits a better consolidated morphology compared to EAFD-FA-LFS. 


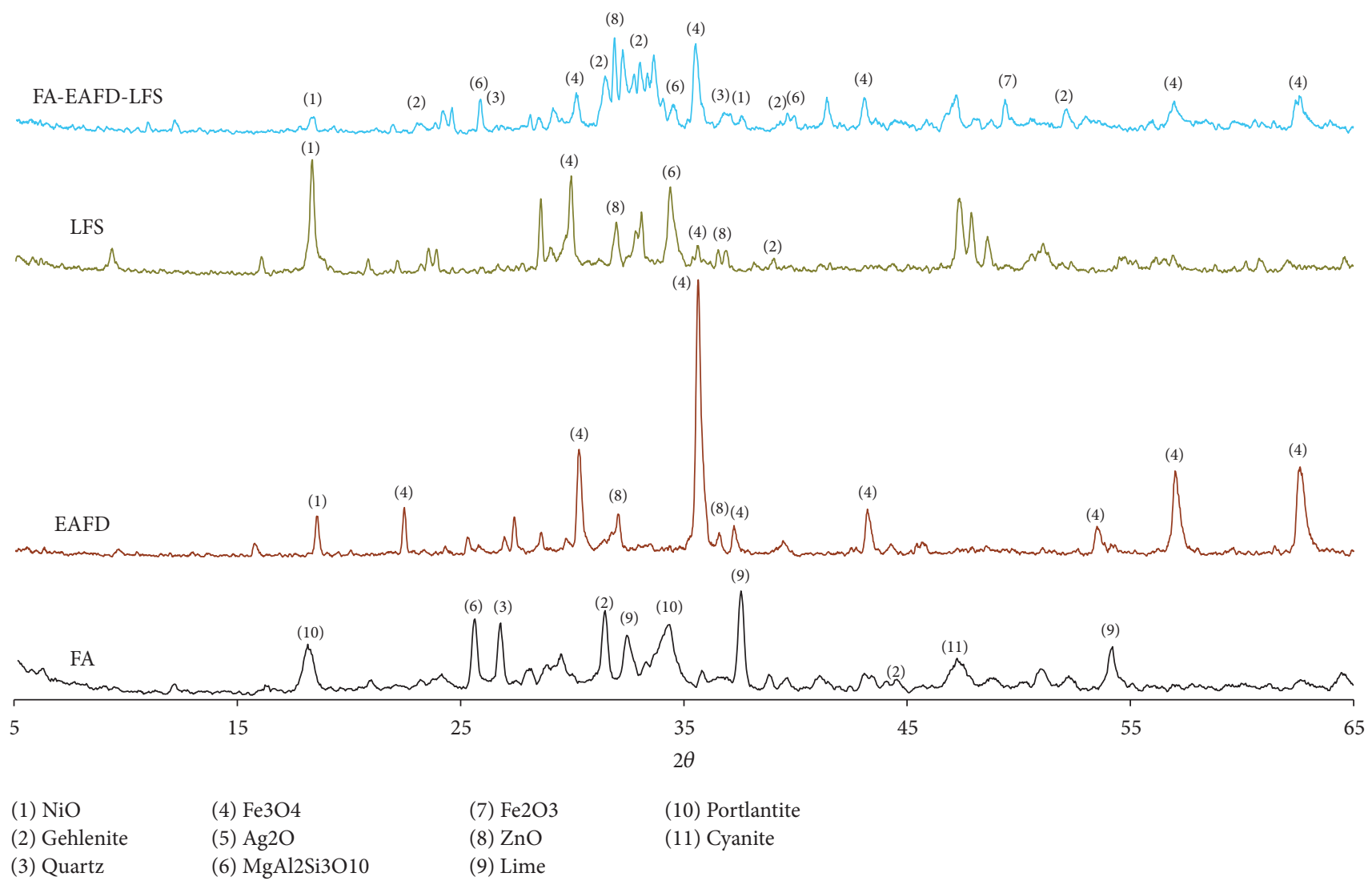

FIGURE 2: XRD patterns of the sintered samples containing only FA, EAFD, LFS, and their ternary mixture. The numbered peaks correspond to the identified phases, shown in the legend (below the figure).
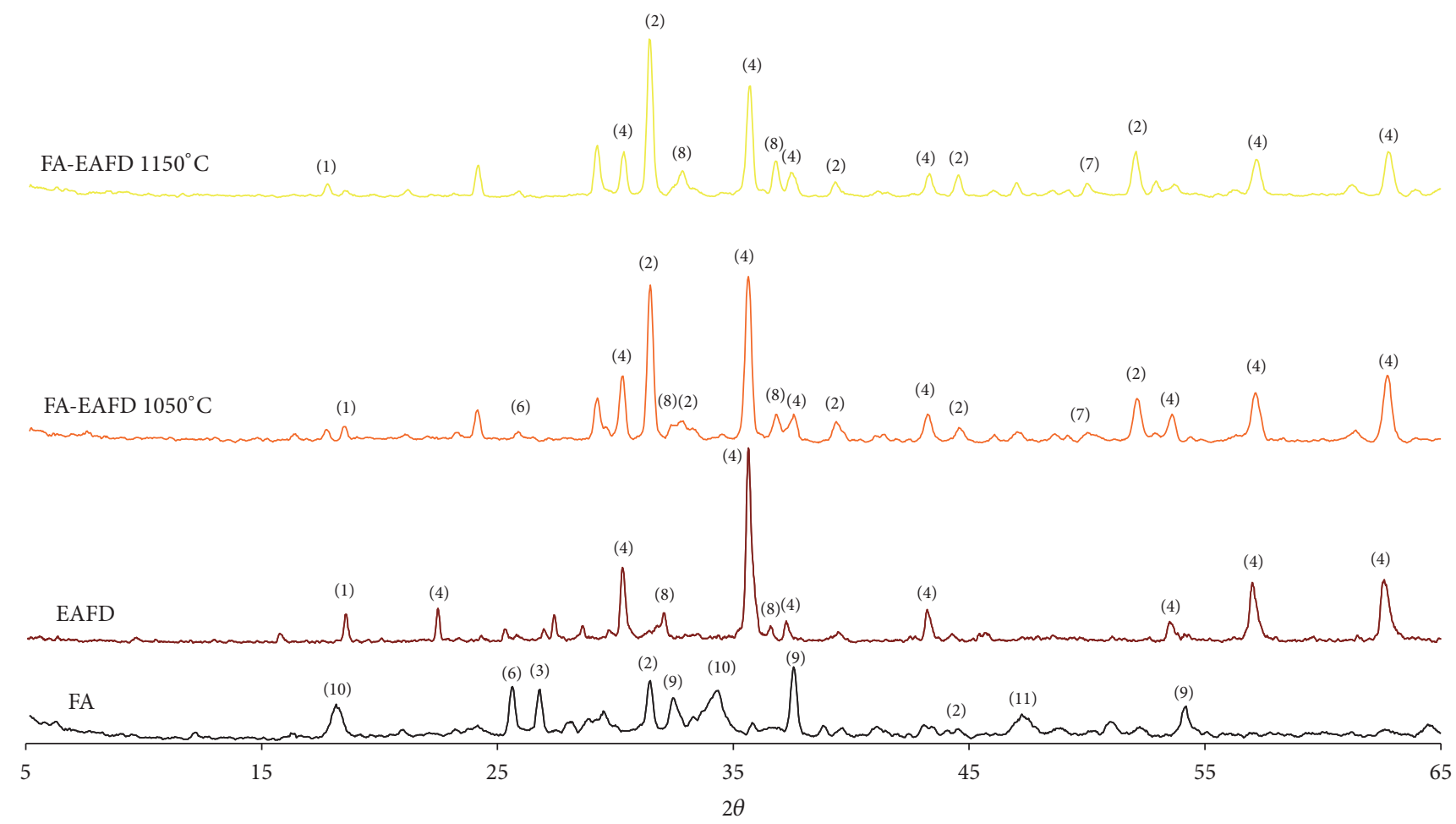
(1) $\mathrm{NiO}$
(4) $\mathrm{Fe} 3 \mathrm{O} 4$
(7) $\mathrm{Fe} 2 \mathrm{O} 3$
(10) Portlantite
(2) Gehlenite
(5) $\mathrm{Ag} 2 \mathrm{O}$
(8) $\mathrm{ZnO}$
(11) Kyanite
(3) Quartz
(6) MgAl2Si3O10
(9) Lime

FIGURE 3: XRD patterns of the FA, EAFD (sintered at $1050^{\circ} \mathrm{C}$ ), and its mixture, sintered in two different temperatures: 1050 and $1150^{\circ} \mathrm{C}$. 


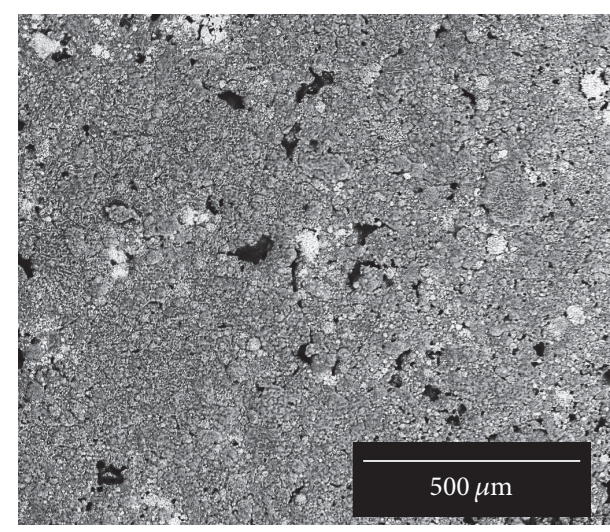

(a)

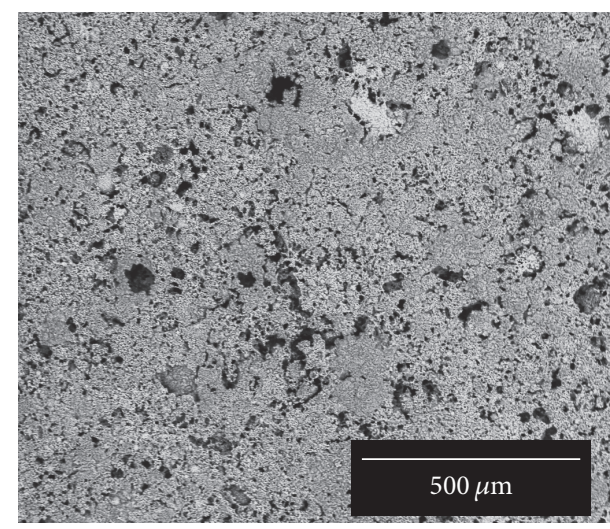

(c)

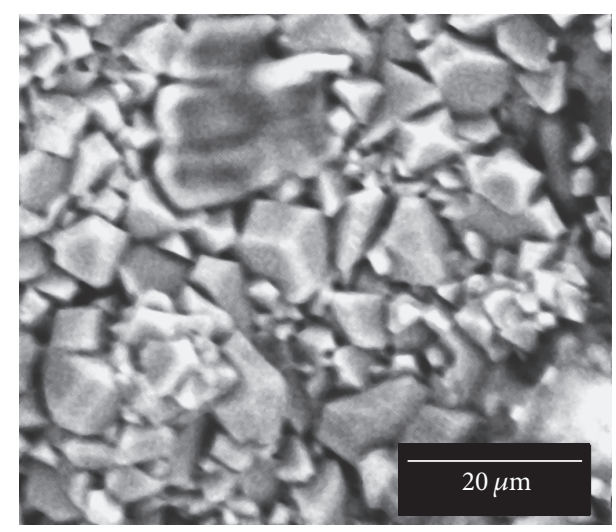

(b)

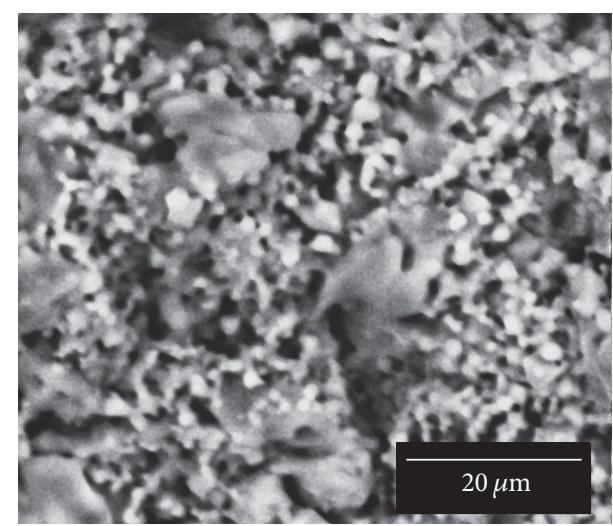

(d)

FIgURE 4: SEM images of the EAFD-FA mixture ( $\mathrm{a}$ and $\mathrm{b}$ ) as well as of the EAFD-FA-LFS mixture (c and d), both sintered at $1150^{\circ} \mathrm{C}$.

SEM micrographs of EAFD-FA-LFS samples sintered at $950^{\circ} \mathrm{C}$ and $1150^{\circ} \mathrm{C}$ are shown in Figures 5(a) and 5(b), respectively. The morphology of both samples reveals the effective densification of the ceramic mixtures. Particularly in the ceramic sample sintered at $1150^{\circ} \mathrm{C}$ (Figure 5(b)), a more interconnected network with sintering necks can be observed. Some glassy structures are also found especially in this sample (sintered at $1150^{\circ} \mathrm{C}$ ) (see large areas in Figure 5(b) without well-specified grain boundaries). This is in good accordance with the occurrence of the amorphous phase in the XRD patterns. Separate FA cenospheres (approximately $1-2 \mu \mathrm{m})$ were also found inside the ceramic bodies, and both samples seem to be porous (Figures 5(a) and 5(b)). In Figure 5(c), an EDS spectrum, taken from the sample area included in Figure 5(a), is shown. All elements that are present in the EDS spectrum were also represented in the phase composition of the sample identified from the XRD measurements. Similar EDS spectra were obtained from the rest of the ceramic samples.

Various properties were studied in order to assess the performance of the ceramic compacts produced. Volume change, apparent density, water absorption, and Vickers microhardness, are shown in Figures 6(a), 6(b), 6(c), and 6(d), respectively. FA exhibits a highly positive volume change while EAFD has a highly negative volume change. The positive volume change (expansion) of FA can be attributed to the collapse of the amorphous and crystalline aluminosilicate phases (e.g., $\mathrm{MgAl}_{2} \mathrm{Si}_{3} \mathrm{O}_{10}$ ) contained in FA [29]. The collapse of the silicate phases occurs at temperatures around $950^{\circ} \mathrm{C}$ [30]. The positive volume change of FA is more pronounced in the temperature of $1050^{\circ} \mathrm{C}$, while in higher temperatures $\left(1150^{\circ} \mathrm{C}\right)$ this variation is not that evident. On the other hand, the negative volume change (shrinkage) of EAFD can be attributed to the increased densification capability of EAFD due to the sintering of the metal oxides. The negative volume change in EAFD is more pronounced $(-30 \%)$ at higher temperatures $\left(1150^{\circ} \mathrm{C}\right)$, which is in good agreement with the literature [31]. In the produced mixtures (FA-EAFD and FA-EAFD-LFS), an intermediate behavior (shrinkage or expansion) is observed depending on the FA and EAFD composition in the mixture. The volume change on the mixtures is rather not significant due to the antagonistic effect of FA and EAFD on the volume change.

On the other hand, the apparent density (Figure 6(b)) of the materials produced lies in the range of $2.8-3.0 \mathrm{~g} / \mathrm{cm}^{3}$. Except for FA, by increasing the processing temperature from 1050 to $1150^{\circ} \mathrm{C}$, the apparent density slightly increases. This is also consistent with the SEM observations (Figures 6(a) and 6(b)), from which a higher densification degree was observed for the mixture processed at the highest temperature $\left(1150^{\circ} \mathrm{C}\right)$. 


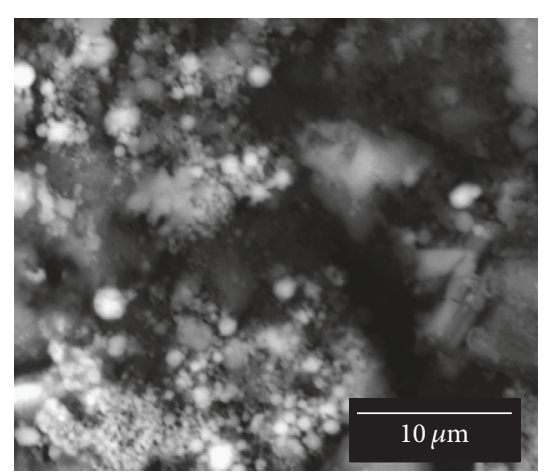

(a)

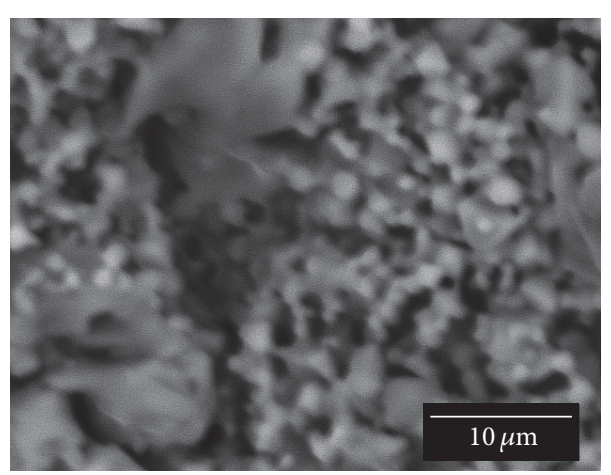

(b)

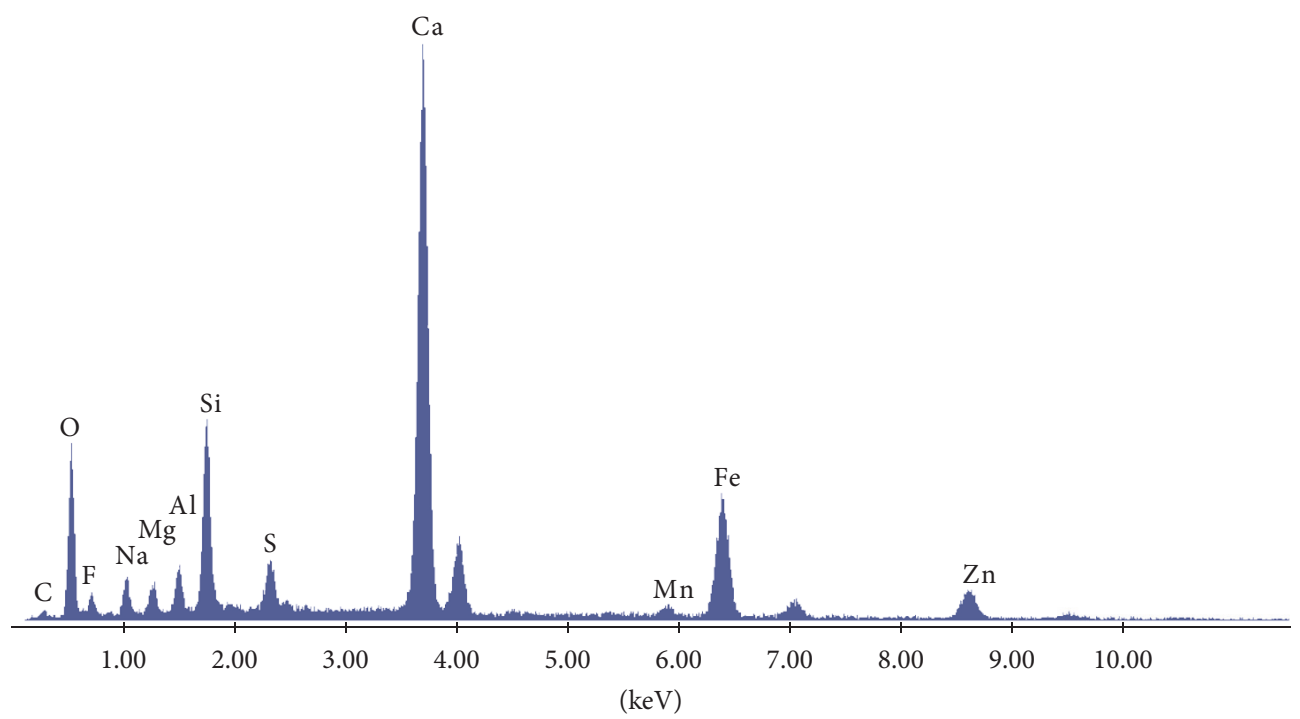

(c)

Figure 5: SEM images of two EAFD-FA-LFS samples sintered at $950^{\circ} \mathrm{C}$ (a) and at $1150^{\circ} \mathrm{C}$ (b). The EDS spectrum (c) was taken from the sample area included in image (a).

FA is a high specific surface area material, with enhanced absorption capabilities due to its high porosity and surface area [29]. The water absorption (Figure 6(c)) of FA is much higher than the one of EAFD. Furthermore, the water absorption of FA increases significantly (almost doubles) with a temperature increase from 1050 to $1150^{\circ} \mathrm{C}$. This may be attributed to the removal of preexisting volatile (burnable) matter at higher temperatures [32]. The water absorption of the FA-EAFD and FA-EAFD-LFS mixtures exhibits intermediate values, in the range of $20-30 \%$. However, by increasing the processing temperature (to $1150^{\circ} \mathrm{C}$ ), the water absorption slightly reduces. The latter should be ascribed to the higher densification degree achieved at higher temperatures and the blockage of sorption sites (pores) which exist in FA.

The Vickers (HV) testing results reveal the important role of EAFD loading in the microhardness of the ceramic compacts. Actually, EAFD should be much harder than the other solid residues used in this study due to its metal oxides content. In that sense, the highest HV values were obtained for the binary mixture (FA-EAFD), as it contains higher EAFD loadings. Much lower HV values were recorded for the ternary mixture (FA-EAFD-LFS). The aforementioned behavior becomes more pronounced at higher temperatures $\left(1150^{\circ} \mathrm{C}\right)$ due to the higher densification degree achieved. Indeed, the hardness of the binary mixture (FA-EAFD) increases from $10 \mathrm{HV}$ to $234 \mathrm{HV}$ by increasing the temperature from 1050 to $1150^{\circ} \mathrm{C}$.

\section{Conclusions}

Sustainable ceramic materials deriving from $100 \%$ industrial waste by-product mixtures were successfully produced in this study. The elemental and structural analyses (XRF, $\mathrm{XRD}$ ) indicated that the waste by-products consist in various valuable mineralogical phases (quartz, metal oxides, etc.) that are useful for the production of advanced materials. However, the recorded differences in chemical and mineralogical composition of the secondary resources being used as the raw materials for the production of ceramics should be taken into consideration. Morphological observations via SEM and apparent density measurements denote the successful densification of waste by-products towards the formation 


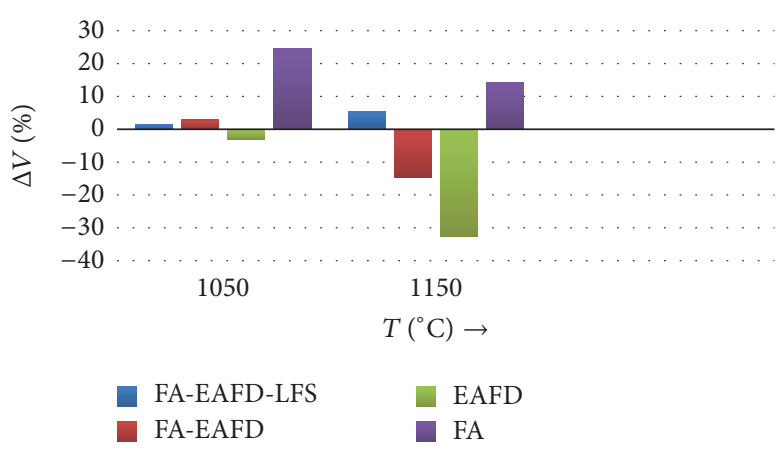

(a)

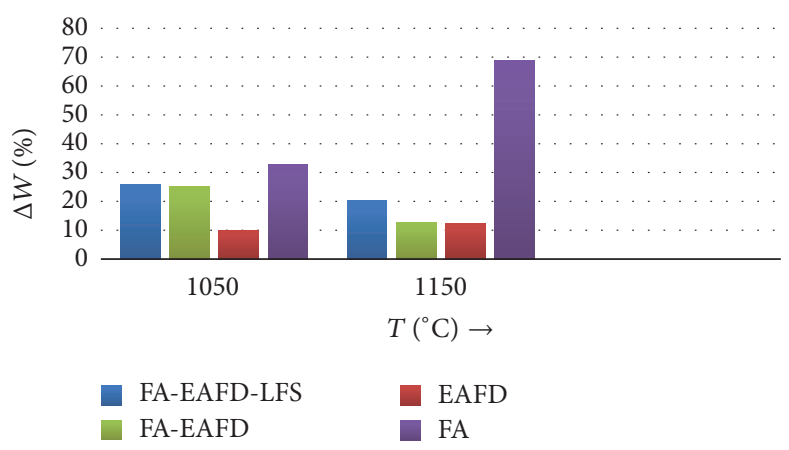

(c)

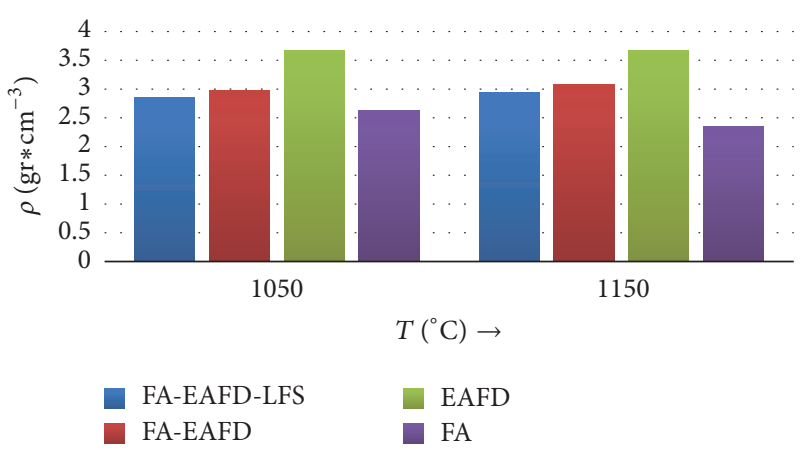

(b)

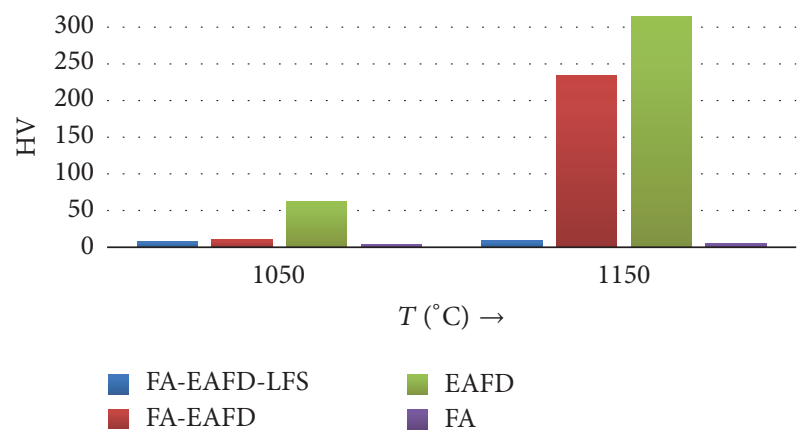

(d)

FIGURE 6: Volume change (a), apparent density (b), water absorption (c), and Vickers microhardness (d), for all the samples produced in this work.

of sintered ceramic compacts. Moreover, volume change, water absorption, and microhardness measurements conducted contribute to assess the performance of the ceramics produced. FA and EAFD ratio in the compacted ceramic mixtures seems to play a crucial role in the attained properties. An antagonistic effect of FA and EAFD on the volume change leads to intermediate volume change values for the ceramic mixtures. Furthermore, the addition of FA plays a significant role in the water absorption of the ceramic mixtures. Both the binary (FA-EAFD) and the ternary mixture (FA-EAFD-LFS) exhibit water absorption values lower than $20 \%$, acceptable for traditional ceramics. Nevertheless, the addition of EAFD mainly affected the Vickers microhardness of the compacted ceramic mixtures. Rather significant microhardness values $(234 \mathrm{HV})$ were recorded for the binary (FA-EAFD) ceramic mixture at higher processing temperatures. The processing temperature also influences the other properties examined and the quality of the compacted ceramic mixtures. Consequently, the results presented here indicate that value-added ceramic products can be produced mainly from compacted FA-EAFD by-product mixtures, because these ceramic materials exhibit enhanced physicomechanical properties. Finally, additional properties testing is underway so as to further explore potential fields of technological applications (e.g., insulation), in which the produced ceramics may be used.

\section{Conflicts of Interest}

The authors declare that there are no conflicts of interest regarding the publication of this paper.

\section{Acknowledgments}

This research has been cofinanced by the European Union (European Social Fund (ESF)) and Greek National Funds through the Operational Program "Education and Lifelong Learning" of the National Strategic Reference Framework (NSRF) Research Funding Program ARCHIMEDES III (Scientific Coordinator: Associate Professor Vayos G. Karayannis): Investing in Knowledge Society through the European Social Fund.

\section{References}

[1] B. Das, S. Prakash, P. S. R. Reddy, and V. N. Misra, "An overview of utilization of slag and sludge from steel industries," Resources, Conservation and Recycling, vol. 50, no. 1, pp. 40-57, 2007.

[2] V. G. Karayannis and A. K. Moutsatsou, "Synthesis and characterization of nickel-alumina composites from recycled nickel powder," Advances in Materials Science and Engineering, vol. 2012, Article ID 395612, 2012.

[3] I. B. Singh, K. Chaturvedi, R. K. Morchhale, and A. H. Yegneswaran, "Thermal treatment of toxic metals of industrial hazardous wastes with fly ash and clay," Journal of Hazardous Materials, vol. 141, no. 1, pp. 215-222, 2007.

[4] M.-T. TANG, J. PENG, B. PENG, D. YU, and C.-B. TANG, "Thermal solidification of stainless steelmaking dust," Transactions of Nonferrous Metals Society of China (English Edition), vol. 18, no. 1, pp. 202-206, 2008.

[5] T. Sofilić, A. Rastovčan-Mioč, Š. Cerjan-Stefanović, V. Novosel-Radović, and M. Jenko, "Characterization of steel mill 
electric-arc furnace dust," Journal of Hazardous Materials, vol. 109, no. 1-3, pp. 59-70, 2004.

[6] A. T. Machado, F. R. Valenzuela-Diaz, C. A. C. de Souza, and L. R. P. de Andrade Lima, "Structural ceramics made with clay and steel dust pollutants," Applied Clay Science, vol. 51, no. 4, pp. 503-506, 2011.

[7] P.-T. Teo, A. S. Anasyida, P. Basu, and M. S. Nurulakmal, "Recycling of Malaysia's electric arc furnace (EAF) slag waste into heavy-duty green ceramic tile," Waste Management, vol. 34, no. 12, pp. 2697-2708, 2014.

[8] V. Mymrin, R. A. C. Ribeiro, K. Alekseev, E. Zelinskaya, N. Tolmacheva, and R. Catai, "Environment friendly ceramics from hazardous industrial wastes," Ceramics International, vol. 40, no. 7, pp. 9427-9437, 2014.

[9] P. S. Polie, M. R. Ilic, and A. R. Popovic, "Environmental impact assessment of lignite fly ash and its utilization products as recycled hazardous wastes on surface and ground water quality," Handbook of Environmental Chemistry, Vol. 5: Water Pollution, vol. 5, pp. 61-110, 2006.

[10] M. Arsenovic, Z. Radojević, Ž. Jakšić, and L. Pezo, "Mathematical approach to application of industrial wastes in clay brick production - Part II: Optimization," Ceramics International, vol. 41, no. 3, pp. 4899-4905, 2015.

[11] V. Karayannis, X. Spiliotis, A. Domopoulou, K. Ntampegliotis, and G. Papapolymerou, "Optimized synthesis of construction ceramic materials using high-Ca fly ash as admixture," Romanian Journal of Materials, vol. 45, no. 4, pp. 358-363, 2015.

[12] V. G. Karayannis, A. K. Moutsatsou, and E. L. Katsika, "Synthesis of microwave-sintered ceramics from lignite fly and bottom ashes," Journal of Ceramic Processing Research, vol. 14, no. 1, pp. 45-50, 2013.

[13] B. Kim and M. Prezzi, "Compaction characteristics and corrosivity of Indiana class-F fly and bottom ash mixtures," Construction and Building Materials, vol. 22, no. 4, pp. 694-702, 2008.

[14] A. Zimmer and C. P. Bergmann, "Fly ash of mineral coal as ceramic tiles raw material," Waste Management, vol. 27, no. 1, pp. 59-68, 2007.

[15] S. Rai, D. H. Lataye, M. J. Chaddha et al., "An alternative to clay in building materials: Red mud sintering using fly ash via taguchi's methodology," Advances in Materials Science and Engineering, vol. 2013, Article ID 757923, 2013.

[16] J. Huang, M. Fang, Z. Huang et al., "Preparation, microstructure, and mechanical properties of spinel-corundum-sialon composite materials from waste fly ash and aluminum dross," Advances in Materials Science and Engineering, vol. 2014, Article ID 789867, 2014.

[17] V. G. Karayannis, A. K. Moutsatsou, and E. L. Katsika, "Recycling of lignite highly-calcareous fly ash into nickel-based composites," Fresenius Environmental Bulletin, vol. 21, no. 8B, pp. 2375-2380, 2012.

[18] A. Karamberi and A. Moutsatsou, "Vitrification of lignite fly ash and metal slags for the production of glass and glass ceramics," China Particuology, vol. 4, no. 5, pp. 250-253, 2006.

[19] A. Olgun, Y. Erdogan, Y. Ayhan, and B. Zeybek, "Development of ceramic tiles from coal fly ash and tincal ore waste," Ceramics International, vol. 31, no. 1, pp. 153-158, 2005.

[20] P. Porreca, E. Furlani, L. Fedrizzi et al., "Sintered ceramics from special waste incinerator ashes and steelmaking slag," Industrial Ceramics, vol. 27, no. 3, pp. 197-203, 2007.

[21] L. F. Vilches, C. Fernández-Pereira, J. Olivares del Valle, and J. Vale, "Recycling potential of coal fly ash and titanium waste as new fireproof products," Chemical Engineering Journal, vol. 95, no. 1, pp. 155-161, 2003.

[22] E. Bernardo, L. Esposito, E. Rambaldi, A. Tucci, Y. Pontikes, and G. N. Angelopoulos, "Sintered esseneite-wollastoniteplagioclase glass-ceramics from vitrified waste," Journal of the European Ceramic Society, vol. 29, no. 14, pp. 2921-2927, 2009.

[23] G. Bantsis, C. Sikalidis, M. Betsiou, T. Yioultsis, and A. Bourliva, "Ceramic building materials for electromagnetic interference shielding using metallurgical slags," Advances in Applied Ceramics, vol. 110, no. 4, pp. 233-237, 2011.

[24] L. S. Pioro and I. L. Pioro, "Reprocessing of metallurgical slag into materials for the building industry," Waste Management, vol. 24, no. 4, pp. 371-379, 2004.

[25] P. Asokan, M. Saxena, and S. R. Asolekar, "Coal combustion residues-environmental implications and recycling potentials," Resources, Conservation and Recycling, vol. 43, no. 3, pp. 239-262, 2005.

[26] M. Ilic, C. Cheeseman, C. Sollars, and J. Knight, "Mineralogy and microstructure of sintered lignite coal fly ash," Fuel, vol. 82, no. 3, pp. 331-336, 2003.

[27] V. Karayannis, A. Moutsatsou, N. Koukouzas, and C. Vasilatos, "Valorization of CFB-combustion fly ashes as the raw materials in the development of value-added ceramics," Fresenius Environmental Bulletin, vol. 22, no. 12C, pp. 3873-3879, 2013.

[28] N. Koukouzas, C. Vasilatos, G. Itskos, I. Mitsis, and A. Moutsatsou, "Removal of heavy metals from wastewater using CFB-coal fly ash zeolitic materials," Journal of Hazardous Materials, vol. 173, no. 1-3, pp. 581-588, 2010.

[29] R. Aiello, F. Testa, and G. Giordano, "Impact of zeolites and other porous materials on the new technologies at the beginning of the new millennium," in Proceedings of the 2nd International FEZA Conference, Elsevier Science, Taormina, Italy, September, 2002.

[30] J. Kovac, A. Trnik, I. Medved, I. Stubna, and L. Vozar, "Influence of fly ash added to a ceramic body on its thermophysical properties," Thermal Science, vol. 20, no. 2, pp. 603-612, 2016.

[31] C. Sikalidis and M. Mitrakas, "Utilization of electric arc furnace dust as raw material for the production of ceramic and concrete building products," Journal of Environmental Science and Health - Part A Toxic/Hazardous Substances and Environmental Engineering, vol. 41, no. 9, pp. 1943-1954, 2006.

[32] K. Pimraksa, M. Wilhelm, and W. Wruss, "A new approach to the production of bricks made of $100 \%$ fly ash," Tile \& brick International, vol. 16, no. 6, pp. 428-435, 2000. 

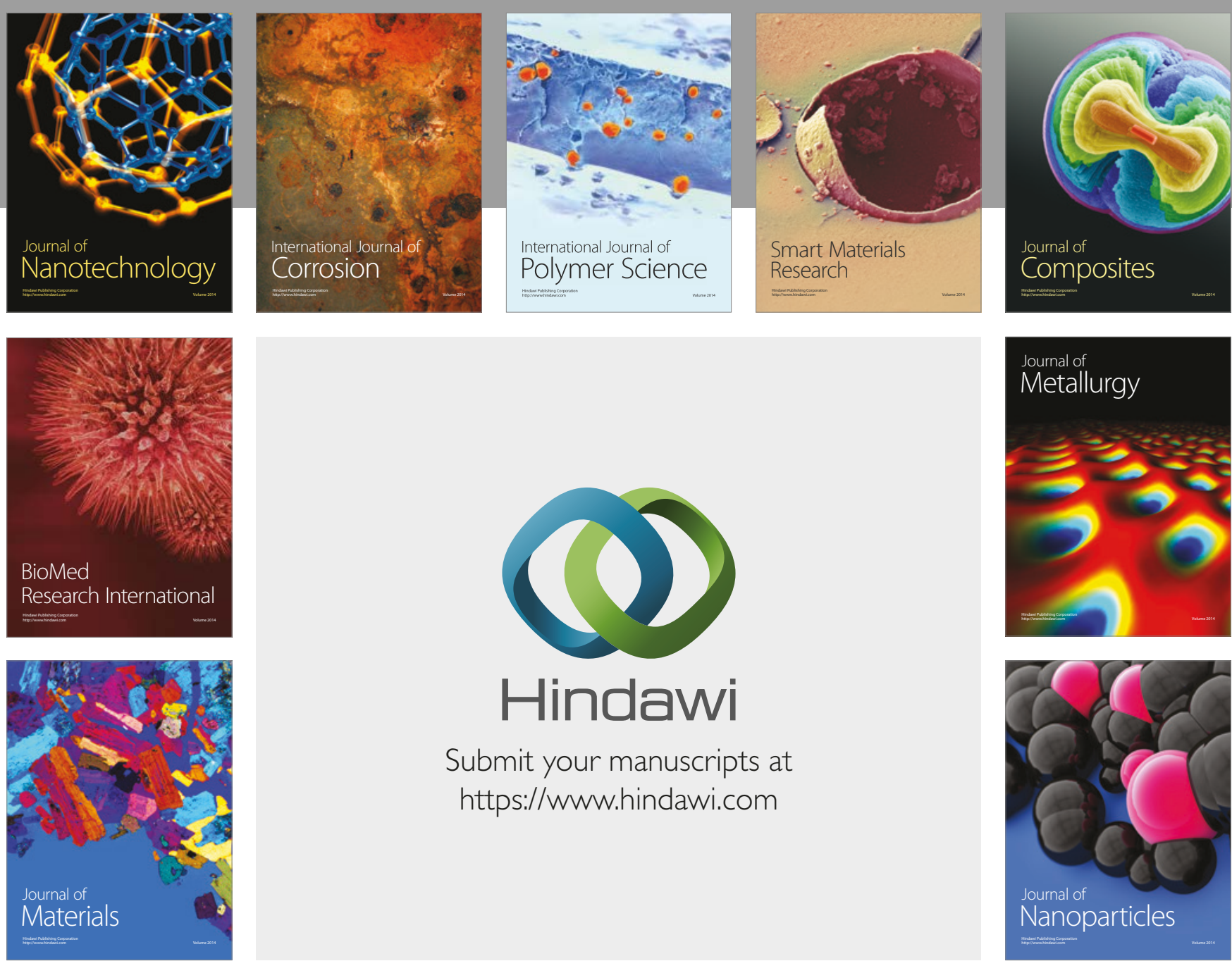

\section{Hindawi}

Submit your manuscripts at

https://www.hindawi.com
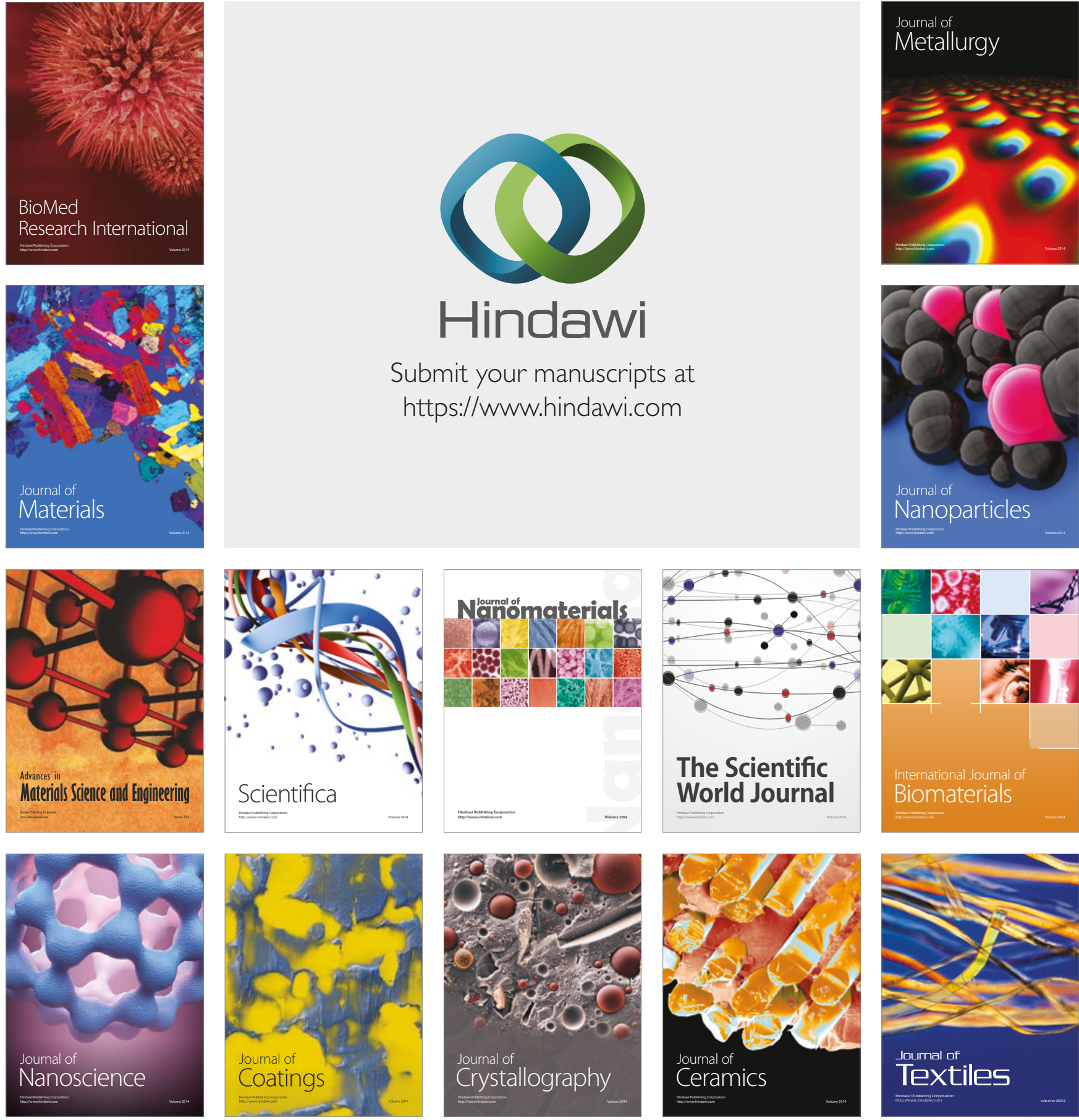

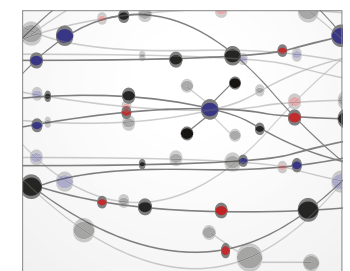

The Scientific World Journal
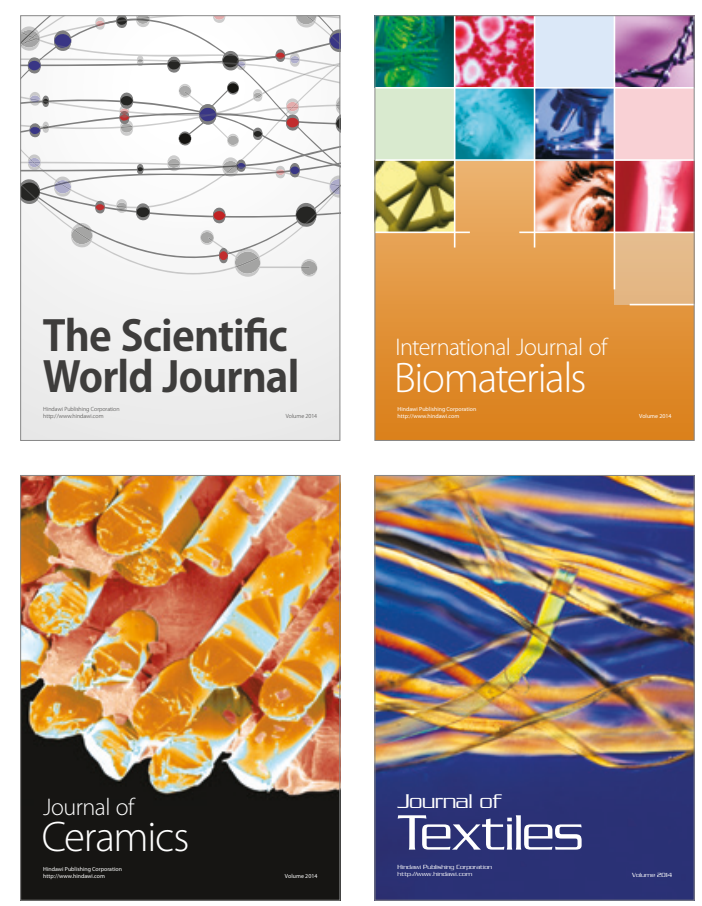